Sir,

\section{Hydroxyproline excretion in idiopathic, congenital, and paralytic scoliosis}

We are glad that Dr. P. F. Benson wrote to you (Archives, 1972, 47, 476) drawing attention to the work on this subject which he published in 1965 (Benson, 1965). Had he been less modest, he might have added that it was the exciting discovery which he made-that urinary hydroxyproline excretion is increased in scoliotic children-which led to the much larger study, subsequently made here by us, which you published (Zorab et al., 1971) confirming his results. We ought to have referred to his earlier work in our paper. In the study of total hydroxyproline excretion in 168 French scoliotic children, we found the higher levels were mostly in those undergoing treatment.

STEPHANIE CLARK and P. A. ZORAB

Paediatric Research Unit, Institute of Diseases of the Chest, London S.W.3.

\section{REFERENCES}

Benson, P. F. (1965). Hydroxyproline excretion in scoliosis. In Proceedings of a Symposium on Scoliosis, held in the Institute of Diseases of the Chest, London, July 1965, p. 47. Ed. by P. A. Zorab. National Fund for Research into Poliomyelitis and other Crippling Diseases, London.

Zorab, P. A., Clark, S., Cotrel, Y., and Harrison, A. (1971). Bone collagen turnover in idiopathic scoliosis estimated from total hydroxyproline excretion. Archives of Disease in Childhood, 46, 828.

\section{Syndrome of growth resistance, obesity, and intellectual impairment with precocious puberty}

Sir,

The paper under this title by MacMillan, Kim, and Weisskopf in the Archives, February 1972, p. 119 prompts me to report a similar patient.

H.G. is the second daughter of parents of normal stature (midparental height $172 \mathrm{~cm}$ ) and was referred at the age of $4 \frac{1}{2}$ years with obesity and delay in speech development. Her birthweight had been $2 \cdot 8 \mathrm{~kg}$ and $\Omega$ her motor development had been slow; she had not walked unaided until the age of $2 \frac{1}{2}$ years. On examination her weight was over the 75th centile while her $\overrightarrow{0}$ height was below the 10th. The obesity was most $\overrightarrow{\mid}$ marked on the trunk; her facies were normal, but her $\vec{\omega}$ hands and feet were noted to be tiny. Her IQ (Stanford Binet) was about 80. A diagnosis of Prader Willi 0 syndrome was made and some dietary restriction advised.

Her subsequent progress is shown in Fig. 1 and $2 . \overrightarrow{0}$ Her weight and height have increased together; at the $\stackrel{\infty}{\infty}$ age of $7 \frac{1}{2}$ years pubic hair and breast development were

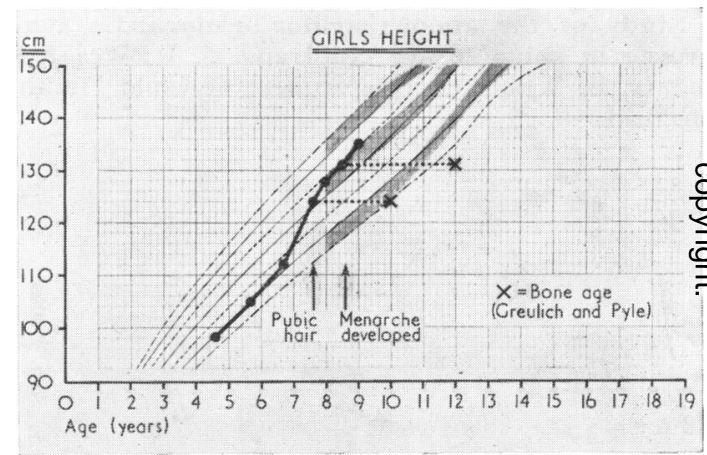

FIG. 1.-Height chart showing progress of patient (৩).

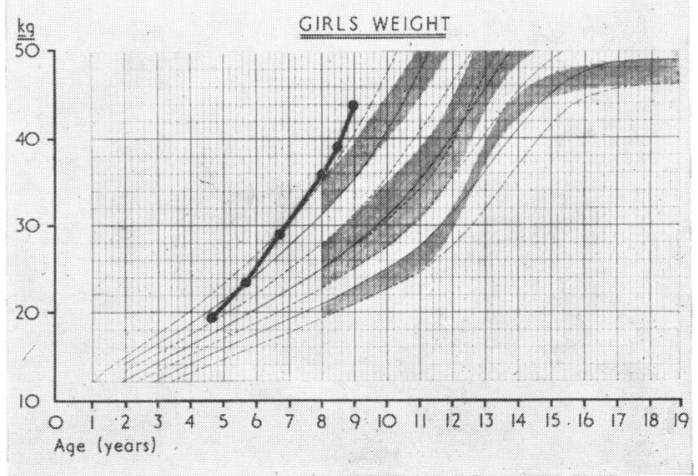

FIG. 2.-Weight chart showing progress of patient (৩). 
TABLE

Investigations

Chromosomes

Maximum plasma growth hormone during Bovril test

Plasma FSH

Plasma LH

Plasma 11 hydroxycorticosteroids Midnight

9 a.m.

Plasma TSH

Serum PBI

$24 \mathrm{hr}$ urinary oestrone

oestradiol

oestriol
Normal

$>50 \cdot 0 \mathrm{IU} / \mathrm{ml}$ $400 \mathrm{mIU} / 100 \mathrm{~m}$ $440 \mathrm{mIU} / 100 \mathrm{ml}$

$1 \cdot 7 \mu \mathrm{g} / 100 \mathrm{ml}$ $12.9 \mu \mathrm{g} / 100 \mathrm{ml}$ $2 \cdot 7 \mu \mathrm{U} / \mathrm{ml}$ $6.0 \mu \mathrm{g} / 100 \mathrm{ml}$ $1 \cdot 5 \mu \mathrm{g}$

$1 \cdot 3 \mu \mathrm{g}$

$3 \cdot 6 \mu \mathrm{g}$
FSH, follicle-stimulating hormone; LH, luteinizing hormone; TSH, thyroid-stimulating hormone; PBI, protein-bound iodine. noticed and regular menstruation began at $8 \frac{1}{2}$ years. Since the age of $7 \frac{1}{2}$ years her bone age has been significantly advanced and therefore her predicted adult height is below normal. At the age of $8 \frac{1}{2}$ years she was admitted for some investigations the results of which are given in the Table. In other ways she has remained well and she has continued to attend a normal school.

The clinical picture and laboratory findings in this girl support the suggestion that some patients with features of the Prader Willi syndrome develop precocious puberty as a result of disturbed hypothalamic function.

J. M. PARKIN The Royal Victoria Infirmary, Children's Department, Victoria Road, Newcastle upon Tyne NE1 4LP. 